\title{
ENGAGING UNMOTIVATED EFL LEARNERS IN CLASSROOM TALK
}

\author{
Haifa Alnofaie \\ Asst. Prof., Taif University, Saudi Arabia, haifa.alnofaie@gmail.com
}

\begin{abstract}
The aim of this paper is to demonstrate a teacher's efforts in engaging her unmotivated EFL learners in classroom talk. The paper identifies the teacher's elicitation techniques during the third turn of triadic exchanges for extending turn-taking. It also identifies the types of learner initiatives that created learning opportunities. The teacher and author of this paper introduced eight Saudi EFL learners (aged 18) to a short mystery story, before requiring them to take turns in classroom talk. 40 minutes of classroom interaction were recorded and analysed qualitatively. Informed by the principles of Conversation Analysis (CA) methodology, the paper shows that the teacher's role moved beyond giving negative or positive feedback. Her role involved extending learners' responses by inviting disagreement, suggesting alternatives, paraphrasing and shaping learners' responses, linking learners' contributions and increasing wait-time. These efforts engaged learners in different types of turn taking, including presenting new ideas, building on classmates' ideas, disagreeing with others and extending one's turn. It was found that learners not only engaged in turn taking during interaction but also learned how to use the new language. These findings add to the small body of available literature on elicitation techniques that involve learners in extended turns when creating space for learning. It is hoped that the findings discussed in this paper will inform EFL teaching practices. More investigation is needed to shed light on how to engage unmotivated EFL learners in classroom interaction using appropriate teaching methods.
\end{abstract}

Keywords: unmotivated learners, EFL, elicitation techniques, turn taking, learner initiatives, learning opportunities

\section{INTRODUCTION}

EFL language teachers often are faced with the challenge of increasing the enthusiasm of unmotivated learners. Research on EFL motivation in the classroom has attributed learners' low motivation to various factors, such as the emphasis on writing skills at the expense of other language skills, the use of uninteresting materials, the absence of a link between language courses and future careers, the lack of rapport between teachers and learners and a dearth of technology use in the classroom (Madrid, 2002; Bacha and Bahous, 2011; Papi and Abdollahzadeh, 2012). The issue of teacher motivational strategies has not been researched widely (Papi and Abdollahzadeh, 2012). Unfortunately, the few existing studies are limited to investigating teachers' and learners' perceptions of motivational strategies, relying on quantitative measures (Papi and Abdollahzadeh, 2012). A very limited number of studies has investigated how teachers apply motivational strategies in real classroom environments, using observations and self-evaluations 
(Guilloteaux and Dornyei's, 2008; Papi and Abdollahzadeh, 2012). By analysing classroom discourse qualitatively, this paper examines a teacher's motivational practice of inviting unmotivated learners to take turns in classroom talk.

\section{MOTIVATING LEARNERS TO SPEAK THE NEW LANGUAGE}

Engaging EFL learners in speaking is a challenging task for teachers, a task that becomes more challenging if learners are unmotivated to learn the language. Research in the Saudi context has shown high speaking anxiety rates among Saudi learners of English, which might affect their motivation levels (Alrabai, 2014; AlSaraj, 2014). This situation raises the question of how to encourage unmotivated learners to take turns in classroom talk when they may feel anxious about speaking the new language.

In classroom discussions, learners are expected to engage actively in talk by demonstrating different types of turns. Waring (2011) suggests a typology of turns initiated by learners. According to this typology, learners initiate turns to exploit an assigned turn, volunteer a response or initiate a new sequence. Adding to Waring's (2011) typology of learner initiatives, Brown and Kennedy (2011) have identified the types of utterances that occur in turn taking: presenting new ideas, building on others, disagreeing with others and extending one's turn. It should be noted here that learner initiatives create learning opportunities (Waring, 2011). During turn taking, learners can learn to use new words and grammar; ultimately, such opportunities can enhance learners' consciousness about appropriate language use.

In order to allow for the above-mentioned types of turns and utterances in classroom talk, teachers must employ certain techniques to facilitate learners' engagement in turn taking. The literature has identified the following effective techniques for engaging learners in turn taking: asking referential questions, extending wait-time and shaping learner contributions through paraphrasing and feedback $(\mathrm{Li}, 2011$; Walsh and $\mathrm{Li}$, 2013). Brown and Kennedy (2011) have noted additional techniques, such as linking learners' contributions and building on learners' talk. Based on an analysis of classroom talk, the following section highlights the techniques used in one EFL classroom to encourage turn taking. It also discusses learner engagement in different types of turns.

\section{A SNAPSHOT FROM AN EFL CLASSROOM}

The context of this paper is a private Saudi college. The author of this paper was teaching college students in their preparatory year, which is compulsory in all Saudi private and government colleges. During this year, learners take courses including English, math and communication. They can start their undergraduate degrees only if they pass this compulsory year. The teacher had eight EFL learners in her listening and speaking class, all of whom were repeaters of the preparatory year because they previously did not pass their English course. The learners were assigned to use the same listening and speaking textbook as the previous year. The textbook covered a wide range of topics related to learners' lives, such as climate change, tourism and philanthropy. It also included various tasks requiring learners to engage in short conversations. Although the textbook materials were not new to these learners, they were not actively participating in talk. During such tasks, only a couple of learners would answer the questions, and their answers tended to be very short (i.e., a word or a few words). In one of her classes, the teacher introduced her learners to an audio mystery story (see Appendix A). The mystery was cognitively demanding because the learners had to analyse the events and reach a conclusion. They were divided into groups, and each group had to provide a conclusion. The classroom interaction was analysed using the principles of Conversation Analysis (CA) (see Appendix B). The extracts below demonstrate the efforts made by the teacher and the eight learners to maintain the flow of talk and to extend turns.

\section{Extract 1}

9. T: OK let's move to the second group. Do you agree with the first group?

10.H: No

11.T: No! Okay: we have a different answer here (.)

12.H: She has not seen (.) a murderer

13.T: $\uparrow$ What does that mean she has not seen a murderer? (.2)

14.H: She was l-looking for a new man and e:::r

15.T: She was looking for someone who is special (.) she was looking for a new man (.)

16. $\downarrow$ do you think she was looking for someone who is $\uparrow$ special maybe even if he is a murderer? 
17.H: She... [she did not want a rich man

18.T: [She did not want a rich man because she is rich $\uparrow$ so she is not mentally ill because

19. she was looking for a different man

20. ((Some students are silent; others whisper))

The teacher requests an answer from the other group. $\mathrm{H}$ provides the teacher with an answer (line 10) and extends her view in line 12. The teacher's clarification request in line 13 encourages $H$ to paraphrase her answer (line 14). $\mathrm{H}$ struggles to find the right words, and the teacher scaffolds her contribution by reformulating her answer (lines 15-16). Although the teacher requests clarification (line 16), H's turn in line 17 is to extend and clarify the view previously stated in line 14 and not to respond to the teacher's question. This turn by $\mathrm{H}$ (line 17) represents one type of learner initiative: exploiting an assigned turn (Waring, 2011). The teacher reformulates H's response and repeats her previous answer (lines 18-19). Such paraphrasing and shaping of contributions provides learners with opportunities to learn appropriate uses of the new language (Walsh and $\mathrm{Li}, 2013$ ). This extract demonstrates how the teacher reformulated responses and requested clarification in order to extend the learners' turns. Extract 2 exemplifies other efforts encouraging various types of turn taking.

\section{Extract 2}

$21 \mathrm{~T}$ : $\uparrow$ But if you remember in the sto:ry he is ugly he is thin pale and ill so do you think he is

22 a special man (.) someone who is murderer ill and pale

$23 \mathrm{H}$ : She love strange man

$24 \mathrm{~T}$ : Do you think she likes strange behaviour? Is that what you mean?

$25 \mathrm{H}:{ }^{\circ}$ Yeah $^{\circ}=$

$26 \mathrm{Y}$ : =But this lady is still abnormal that's why she choose this man.

$27 \mathrm{~T}$ : You think she is abnormal and $\uparrow$ what's wrong with her choice? Do you think her choice

28 is wrong?

The teacher challenges H's view (lines 21-22), and $\mathrm{H}$ manages to provide another possible explanation (line 23). This interaction might indicate that statements that challenge learners' higher-order thinking skills (i.e., analysis, synthesis and evaluation) could improve the quality of classroom interaction. The teacher's clarification request (line 24) encourages $Y$ to initiate a turn, without being selected, to disagree with H's answer (line 26). Y's initiative represents volunteering a response for the purpose of expressing disagreement, one of the learner initiatives identified by Waring (2011). The next extract (Extract 3) illustrates a conversation discussing the second question regarding this mystery: who killed Clay?

\section{Extract 3}

31.T: One group says that she is suffering from a mental disorder another group disagrees.

32. now look at the second question which is=

33.Ss: = Who killed Clay?

34.T: Who killed Clay?

35. ((background noise))

36. T: $\uparrow$ Yes ladies listen to the first group.

37.R: Danielle's friend killed Clay because may be she want to marry this man ((laughs))

38.T: You think Helen wants to marry Clay

39.R: Yes

40.T: She is jealous! (4)

41.N: Is it wrong?

42.T: No $\mathrm{N}$ there is no right or wrong answer here.

43.N: Good then. 
In Extract 3, R provides a response to the teacher's question (line 37), followed by the teacher's confirmation request (line 38). The extended wait-time (4 seconds) gives $\mathrm{N}$ an opportunity to ask if the answer is wrong (line 42). By requesting confirmation from the teacher, N's turn marks a new sequence, which is another type of learner initiative (Waring, 2011). The traditional interactional pattern in the EFL classroom is IRF: the teacher initiates a question, the learner responds, and finally, the teacher provides feedback. In line 42 above, the learner initiates a question, and the teacher provides a response, leading to the learner's expression of relief. These lines do not display a common interactional pattern. It should be noted here that the challenging design of mysteries might confuse some learners. Therefore, it is the role of the teacher to explain the rationale for mysteries, so learners feel free to say what they think.

\section{Extract 4}

54 T: What made someone kill Clay? (6)

55 Ss: silence

$56 \mathrm{H}$ : May be he kills himself because he feel guilty (.) he is married to a

57 beautiful wife or he loves her=

$58 \mathrm{~S}:=\mathrm{He}$ wants to achieve he want her to live good life with another

59 person

$60 \mathrm{~T}$ : OK H and S (.) he feels that he does not deserve a good lady she

61 should find someone who is much better

62 Ss: Yes

63 L: (2) If someone love someone he can't kill himself I love her $\uparrow$ why I kill myself!

64 ((inaudible noise))

$65 \mathrm{~T}$ : Go ahead $L$ you want to say something.

66 M: Teacher may be Daniel's friend killed Clay because she want to

67 save her friend.

$68 \mathrm{~T}$ : You think Helen cares about Danielle about her life

69 M: Yes

70 T: Who agrees with her?

H's initiative (lines 56-57) is to volunteer a response to the teacher's question. $S$ volunteers another response to build on and clarify H's view (line 58). It seems that the teacher's pause (6 seconds) encourages these initiatives to occur. The teacher then links the two learners' contributions and reformulates their answers in lines 60 and 61 . The teacher's effort to clarify the two learners' answers seems to encourage $L$ to state her opinion, which differs from her classmates (line 63). Without being selected, M takes a turn to introduce another possible option (lines 66-67). In this extract the learners take turns without being selected by the teacher. The teacher's question-what made someone kill Clay?-encourages learners to think about the killer's motives in order to identify the killer. Open-ended questions that encourage higher-order thinking skills can lead to multiple turns for learners. The extract shows that asking referential questions, extending wait-time and linking learners' contributions can lead to a sequence of learner initiatives (Brown and Kennedy, 2011; Li, 2011; Walsh and Li, 2013).

\section{CONCLUSION}

This paper demonstrates how one EFL teacher encouraged unmotivated learners to take turns in classroom talk. The extracts discussed in this paper illustrate some successful techniques used by the teacher to encourage turn taking. The teacher managed to extend learners' responses by asking referential questions, inviting disagreement, suggesting alternatives, paraphrasing and shaping learners' responses, linking learners' contributions and increasing wait-time. Using such elicitation techniques by the teacher and introducing a task that had no right or wrong answer mad the learners confident in taking part in classroom talk, and this was reflected in the various types of turns and utterances they produced. Although learners were unmotivated, they initiated turns to start a new sequence, exploit an assigned turn and volunteer a response. Their utterance types included presenting new ideas, building on others, disagreeing with others 
and extending their turns. There were opportunities for students to learn and practice using the new language by listening to the teacher's reformulation of their answers or increasing their efforts to produce clear utterances. It is hoped that the discussion in this paper will encourage EFL teachers to rethink their practices and come up with new strategies for encouraging their own unmotivated learners.

\section{REFERENCE LIST}

Alrabai, F. (2014). A model of foreign language anxiety in the saudi EFL context. English Language Teaching, 7(7), 82-101. http://doi.org/10.5539/elt.v7n7p82

Al-saraj, T. M. (2016). Foreign language anxiety in female Arabs learning English : case studies, 1229 (April). http://doi.org/10.1080/17501229.2013.837911

Bahous, R., Bacha, N. N., and Nabhani, M. (2011). Motivating Students in the EFL Classroom: A Case Study of Perspectives. English Language Teaching, 4(3), 33-43. http://doi.org/10.5539/elt.v4n3p33

Brown, K., and Kennedy, H. (2011). Learning through conversation: Exploring and extending teacher and children's involvement in classroom talk. School Psychology International, 32(4), 377-396. http://doi.org/10.1177/0143034311406813

Guilloteaux, M. J., and Dornyei, Z. (2008). Motivating language learners: A classroom-oriented investigation of student motivation. TESOL Quarterly, 42(1), 55-77. http:// doi: 10.1002/j.1545-7249.2008.tb00207.x

$\mathrm{Li}$, Li. (2011). 'Obstacles and opportunities for developing thinking through interaction in language classrooms', Thinking Skills and Creativity, 6, pp. 146-158. http://doi:10.1016/j.tsc.2011.05.001

Madrid, D. (2002). The power of the FL teacher's motivational strategies. Cauce, 25, 369-422.

Papi, M., and Abdollahzadeh, E. (2012). Teacher Motivational Practice, Student Motivation, and Possible L2 Selves: An Examination in the Iranian EFL Context. Language Learning, 62(2), 571-594. http://doi.org/10.1111/j.1467-9922.2011.00632.x

Walsh, S., and Li, Li. (2013). Conversations as space for learning. International Journal of Applied Linguistics (United Kingdom), 23(2), 247-266. http://doi.org/10.1111/ijal.12005

Waring, H. Z. (2011). Learner initiatives and learning opportunities in the language classroom. Classroom Discourse, 2(2), 201-218. http://doi.org/10.1080/19463014.2011.614053

\section{APPENDIX A}

\section{Mystery}

Mystery 1 'Married to a murderer' Task Instructions: Listen to the story and answer the 2 questions on the task sheet.

1. Why did Danielle Marry Clay

2. Who killed Clay?

Each group should write their answer on the answer sheet

\section{APPENDIX B}

\section{CA conventions}

Transcription Conventions (Atkinson and Heritage 1984)

[[ ]] Simultaneous utterances - (beginning [[ ) and ( end]])

[ ] Overlapping utterances - (beginning [ ) and (end])

$=$ Contiguous utterances

(0.4) Represents the tenths of a second between utterances 
(.) Represents a micro-pause (1 tenth of a second or less)

: $\quad$ Sound extension of a word (more colons demonstrate longer stretches)

Fall in tone (not necessarily the end of a sentence)

Continuing intonation (not necessarily between clauses)

- $\quad$ An abrupt stop in articulation

? $\quad$ Rising inflection (not necessarily a question)

- Underline words indicate emphasis

$\uparrow \downarrow \quad$ Rising or falling intonation (after an utterance)

$\circ$ Surrounds talk that is quieter

$>\quad$ Surrounds talk that is faster

$<$ Surrounds talk that is slower

(( )) Analyst's notes

(?) Intelligible speech

LOUD increased volume is written in capitals

\$ S Smile voice'

(what) Transcriber unsure

[BOLD] Arabic words are written in BOLD capitals between brackets 